\title{
Volcanic origin of the 1741 Oshima-Oshima tsunami in the Japan Sea
}

\author{
Kenji Satake \\ Active Fault Research Center, National Institute of Advance Industrial Science and Technology, 1-1-1 Higashi, Tsukuba 305-8567, Japan
}

(Received September 25, 2006; Revised January 9, 2007; Accepted January 19, 2007; Online published June 8, 2007)

\begin{abstract}
The generation mechanism of the 1741 Oshima-Oshima tsunami, which is considered to be the most destructive tsunami that has ever originated in the Japan Sea, has been the subject of much debate. The tsunami caused about 2,000 casualties along the Hokkaido and northern Honsu coasts and inflicted damage as far as the Korean Peninsula. The tsunami source is located between recent tsunamigenic earthquakes, but there is no historical record of an earthquake in 1741. In contrast, the records indicate volcanic activity of Oshima-Oshima, including a large-scale sector collapse, although the volume change associated with the subaerial landslide is too small to explain the observed tsunami heights. Recent marine surveys indicate that the landslide extended to the ocean bottom with a volume change of about $2.5 \mathrm{~km}^{3}$, nearly an order of magnitude larger than the subaerial slide. On the basis of mapped bathymetry, the generation of the tsunami is calculated using a simple kinematic landslide model. The tsunami propagation is computed in two different grids-a $6^{\prime \prime}$ grid around the source and a $1^{\prime}$ grid for the entire Japan Sea. A parameter search of the model shows that the observed tsunami heights are best explained by a horizontal slide velocity of $40 \mathrm{~m} / \mathrm{s}$ and a rise time of $2 \mathrm{~min}$. The large vertical drop of the landslide and the coupling of the submarine landslide and tsunami are the main factors responsible for the large tsunami.
\end{abstract}

Key words: Oshima-Oshima, tsunami, volcanic tsunami, sector collapse, landslide, Japan Sea.

\section{Introduction}

In 1741 , a very destructive tsunami originated somewhere in the area around Oshima-Oshima, a small volcanic island off Hokkaido that had become active that same year, causing significant damage on the coasts around the Japan Sea (Fig. 1). On the Hokkaido coast, the estimated maximum tsunami height was $13 \mathrm{~m}$ or more, and total casualties amounted to about 2,000 (Hatori, 1984; Imamura and Matsumoto, 1998; Tsuji et al., 2002). The tsunami inflicted material damage as far as western Japan and the east coast of the Korean Peninsula (Tsuji et al., 1985). Based on the recorded heights of the tsunami, if it were to have been generated by an earthquake, its size would be $M=8.4$ (Abe, 1999). However, there is no historical record documenting the ground motion of an earthquake of this magnitude, even though the eruption sequences and the tsunami damage were documented in detail. The generation mechanism of the 1741 tsunami continues to be open to debate and has yet to be definitively determined despite its importance for assessing volcanic hazard and/or seismic potential along the eastern margin of the Japan Sea.

The eastern margin of the Japan Sea is considered to be a boundary between the Eurasian (or Amurean) and North American (or Okhotsk) plates (e.g., Nakamura, 1983; Seno et al., 1996; Wei and Seno, 1998), where large $(M>7.5)$ tsunamigenic earthquakes have occurred semi-periodically (Fig. 1). In the last two centuries, the 1833 Shonaioki $\left(M=7 \frac{1}{2}\right), 1940$ Shakotan-oki $(M=7.5), 1964$ Niigata

Copyright (c) The Society of Geomagnetism and Earth, Planetary and Space Sciences (SGEPSS); The Seismological Society of Japan; The Volcanological Society of Japan; The Geodetic Society of Japan; The Japanese Society for Planetary Sciences; TERRAPUB.
$(M=7.5), 1983$ Japan Sea $(M=7.7)$, and 1993 Southwest Hokkaido $(M=7.8)$ earthquakes have occurred on this tectonic boundary (Fukao and Furumoto, 1975; Satake, 1986; Tanioka et al., 1995). The sections of the boundary between these earthquake sources may form seismic gaps. One of these lies around Oshima-Oshima between the 1983 Japan Sea and 1993 Southwest Hokkaido earthquakes. Ohtake (1995) assumed that the 1741 tsunami was produced by an earthquake that was the first in the current earthquake cycle and forecasted that the next earthquake would occur between the source regions of the 1833 Shonai-oki and 1983 Japan Sea events. His assumption and subsequent forecast may become invalid if the 1741 tsunami was not generated by an earthquake.

The Oshima-Oshima volcano has a history of violent eruptions. It was last recorded to be active in 1741-1790, after 1500 years of dormancy (Katsui et al., 1977; Katsui and Yamamoto, 1981). According to historical documents, the first eruption started around August 18, 1741. On August 23, the volcanic eruption was visible all along the Hokkaido coast and by around noon of August 25, volcanic ashfall blocked the sunlight and the sky became dark during the day. The most violent eruption occurred around 5 AM hours on August 29 and triggered a sector collapse of the mountain edifice; at which time a loud explosive sound was heard on the Hokkaido coast. Strong eruptions were also recorded several times in the following year (1742), and smoke emission continued until 1790. Frequent magmatic eruptions in this activity period buried most of the amphitheater and produced a central cone.

Previous modeling of the 1741 tsunami based on a volcanic eruption was not successful. Aida (1984) performed 


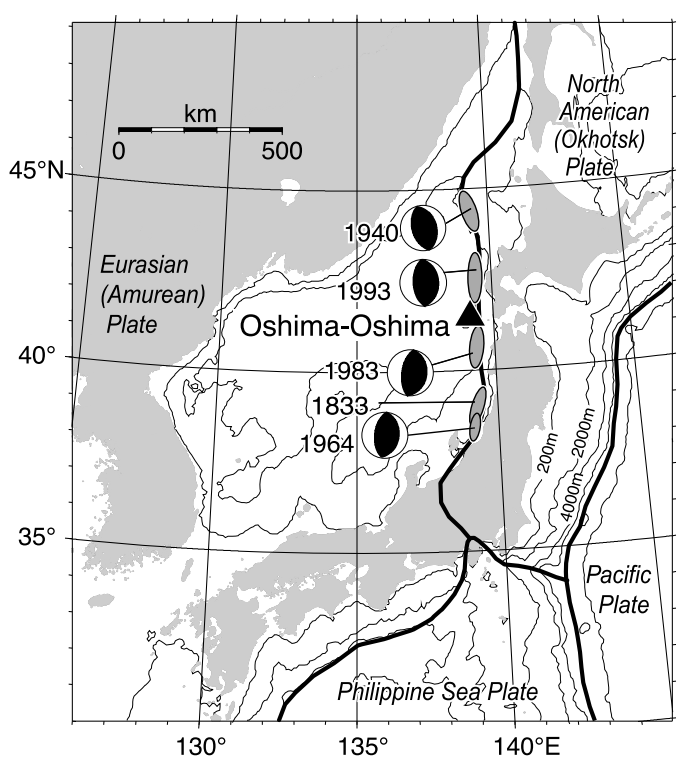

Fig. 1. Oshima-Oshima (solid triangle) is located on the boundary between the Eurasian (or Amurean) and North American (or Okhotsk) plates, where large $(M>7.5)$ tsunamigenic earthquakes have occurred since the 19th century. The source area and focal mechanism of the 20th century earthquakes are from Fukao and Furumoto (1975), Satake (1986), and Tanioka et al. (1995).

tsunami numerical computations based on the subaerial collapse of the volcano. He assumed that the collapse was entirely subaerial and had a volume of $0.4 \mathrm{~km}^{3}$, of which 0.1 $\mathrm{km}^{3}$ flowed into the sea to generate the tsunami. As the calculated tsunami heights from this model were much smaller than the actually observed heights, it has been inferred that a large earthquake triggered the collapse and generated the tsunami (e.g., Katsui and Yamamoto, 1981; Hatori, 1994).

Detailed swath bathymetry surveys have been recently conducted around Oshima-Oshima, and a high-resolution bathymetry map has been published by Hydrographic Department of the Japan Coast Guard. The map shows the two characteristic features of a volcano collapse landslide: an open sector collapse with steep lateral walls and an area of hummocky terrain on the lower slope of the volcano. The arcuate headwall of the landslide is above sea level on Oshima-Oshima island and is partly buried by the active summit crater. Geological surveys using submersibles and deep-tow sonar (Kato, 1997) confirmed that the hummocky terrain consists of debris deposits from the OshimaOshima volcano. Based on the high-resolution bathymetry and topographic data, Satake and Kato (2001) reconstructed the subaerial and submarine sector collapse and debris avalanche of the 1741 eruption and estimated the total volume of the collapse to be $2.4 \mathrm{~km}^{3}$. Based on their calculations, the total volume of debris deposits, which extends as far as $16 \mathrm{~km}$ from the island, is $2.5 \mathrm{~km}^{3}$ and roughly equals the missing slide volume. The slide volume is nearly an order of magnitude larger than the previous estimate of subaerial collapse $\left(0.4 \mathrm{~km}^{3}\right)$.

The 1741 Oshima-Oshima collapse is one of only two large (volume $>1 \mathrm{~km}^{3}$ ) sector collapses to have occurred at island volcanoes in the periods of historical and written records. The other example is Ritter Island in Papua New Guinea in 1888 , where nearly $5 \mathrm{~km}^{3}$ of volcano collapsed (Johnson, 1987; Ward and Day, 2003). The volume change of Oshima-Oshima volcano is similar to that of the 1980 Mt. St. Helens eruption in the USA $\left(2.3 \mathrm{~km}^{3}\right.$; Voight et al., 1981). Both in Ritter Island and Mt. St. Helens, more of the summit of volcano was removed, leaving horseshoeshaped collapse scars. The size of island and bathymetric features around Oshima-Oshima is very similar to those of Stromboli volcano in Italy, where a submarine fan extends more than $10 \mathrm{~km}$ offshore from the subaerial collapse sector, Sciara del Fuoco (Kokelaar and Romagnoli, 1995). The recent small-scale landslide $\left(0.02-0.03 \mathrm{~km}^{3}\right)$ in 2002 caused tsunami damage on Stromboli Island (Tinti et al., 2005).

In this paper, the generation and propagation of the 1741 tsunami are modeled using the volume change and initial

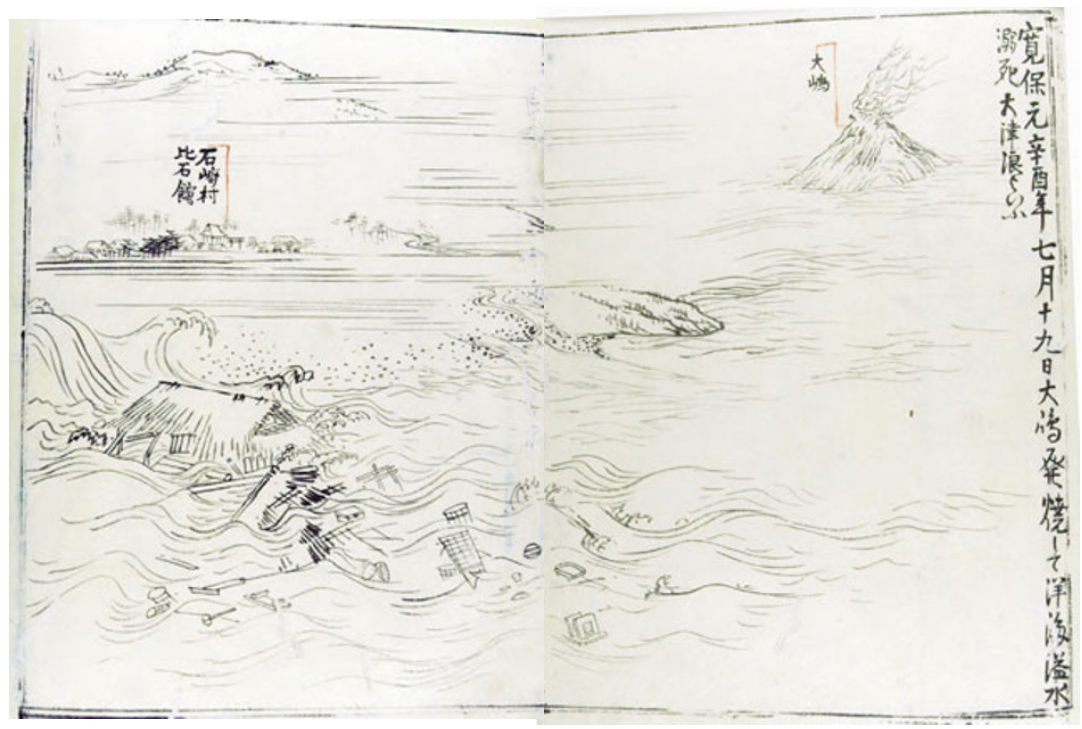

Fig. 2. The eruption of Oshima-Oshima (upper right) and the tsunami on the Hokkaido coast (Ishizaki) on August 29, 1741 (1st year of Kampo, 7th month, 19th day on the Japanese lunar calendar), as described in "Hokkaido Kyu-san Zue". Courtesy of Hakodate City Central Library. 
Table 1. Comparison of the observed and computed (for the best model) heights.

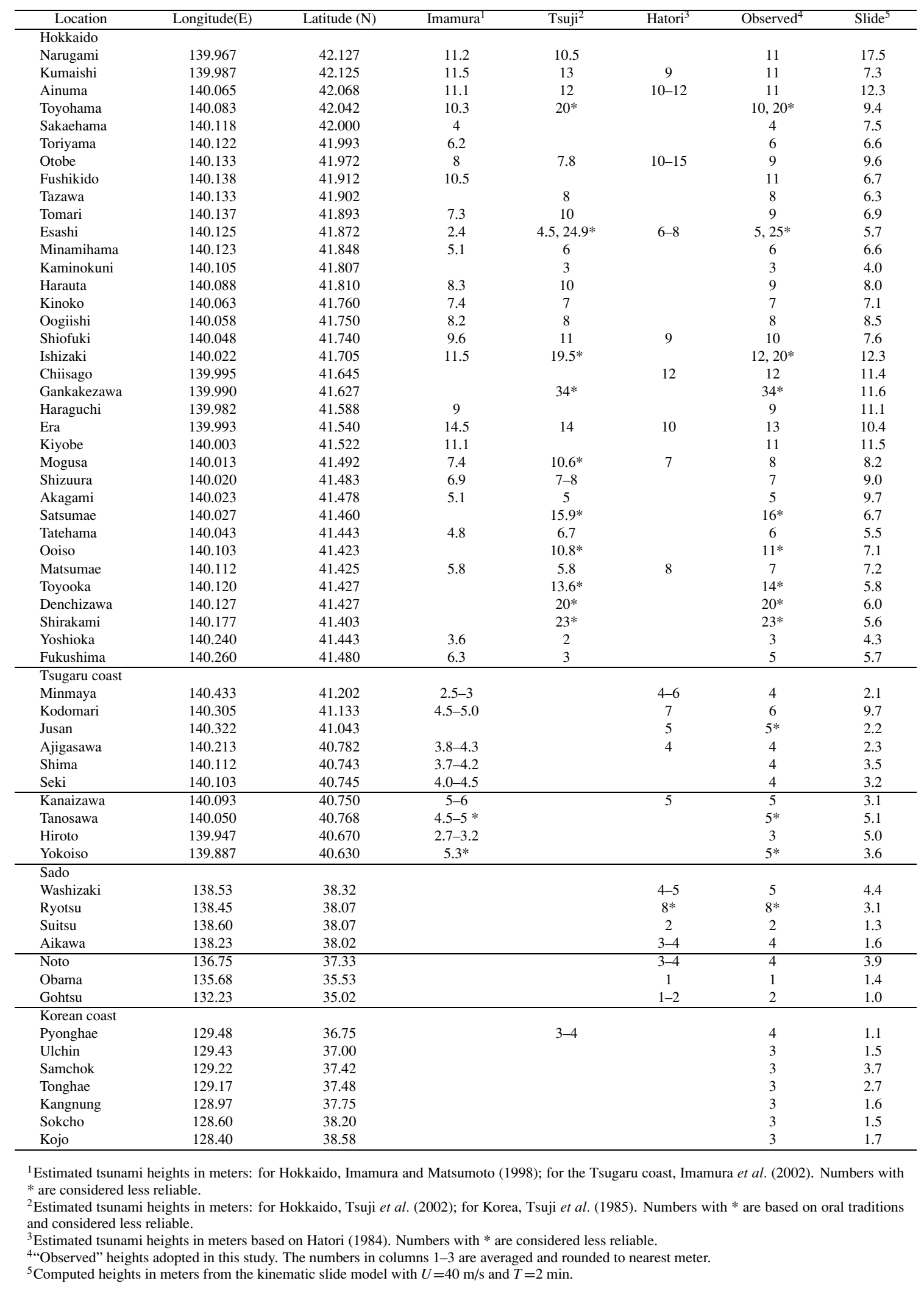

landslide thickness estimated by Satake and Kato (2001). In Section 2, the observed tsunami heights in 1741 are compiled from historical documents and recent field survey reports. In Section 3, a simple kinematic landslide model is introduced to model the submarine landslide. Section 4 de- scribes the numerical computation of tsunami propagation and the statistical parameters for comparing the observed and calculated tsunami heights. Section 5 shows the results that the observed tsunami heights, including those in the western Japan and the Korean coast, can be explained by 


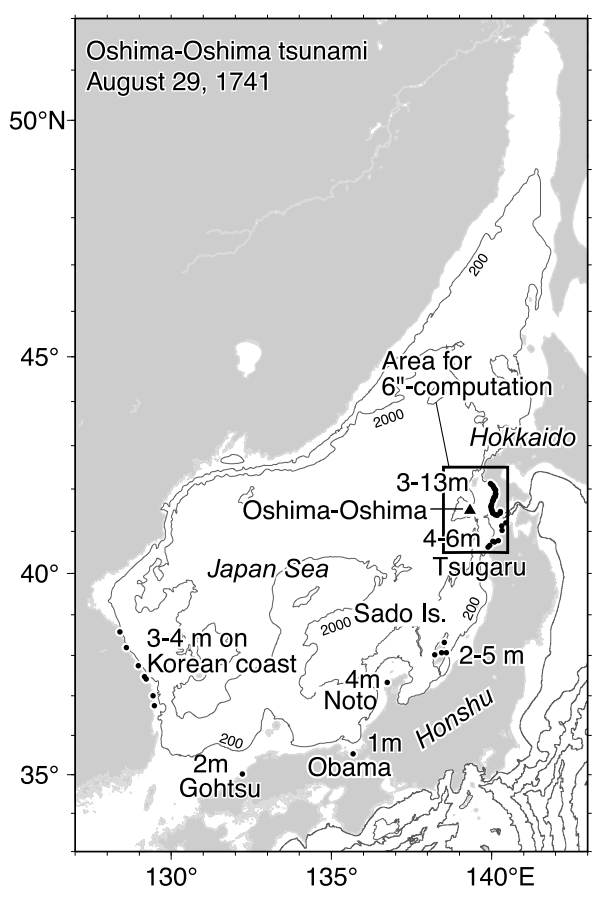

Fig. 3. The recorded tsunami heights around the Japan Sea. The map also shows the computational region and bathymetry for the $1^{\prime}$ grid. Area for a more detailed computation (the $6^{\prime \prime}$ grid) is also shown.

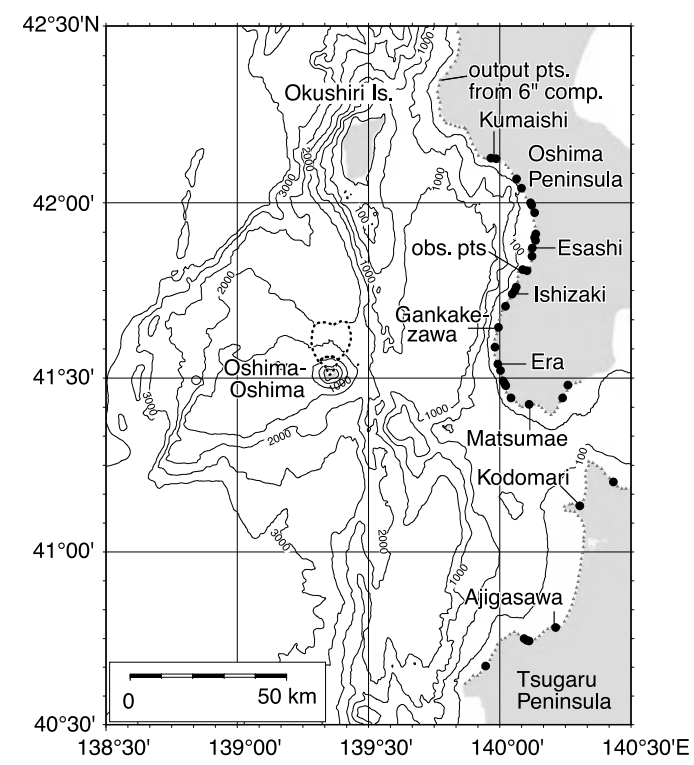

Fig. 4. Detailed bathymetry map around Oshima-Oshima, the Hokkaido and Tsugaru coasts. Tsunami computations on the $6^{\prime \prime}$ grid are made in this region using the shown bathymetry. The areas for landslides and deposits (Fig. 6) are also shown in dotted lines. Locations of output points (triangles) and the observed tsunami heights (solid circles) are also shown.

the landslide source. Section 6 discusses why a submarine or ocean-entering landslide can cause larger tsunamis than earthquakes of comparable rupture areas. Section 7 concludes that the generation mechanism of the 1741 tsunami can be explained by the submarine landslide associated with the volcanic eruption.

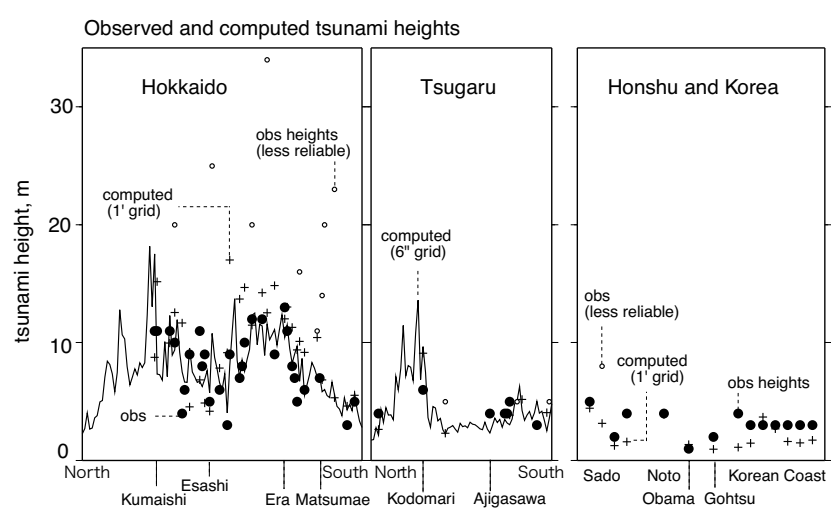

Fig. 5. Comparison of the observed and computed tsunami heights. Circles indicate the observed tsunami heights; solid circles are based on written documents while open circles are based on less-reliable oral histories. Solid curves are the computed tsunami heights (half of the peak-to-trough amplitude) from the kinematic landslide model $(U=40$ $\mathrm{m} / \mathrm{s}$ and $T=2 \mathrm{~min}$ ) on the $6^{\prime \prime}$ grid, while the crosses show the computed heights (peak-to-trough amplitudes) on the $1^{\prime}$ grid. See Figs. 3 and 4 for the locations.

\section{Observed Tsunami Wave Heights}

The 1741 tsunami caused devastating damage along the Hokkaido coast and lesser damage on the Honshu and Korean coasts. More than 30 documents, both original and secondary sources, contain descriptions of the damage that resulted from this tsunami (Tsuji et al., 2002). These documents also describe the eruption and tsunami sequences (Fig. 2), but ground shaking due to an earthquake is not mentioned in any of the documents, although some records do describe a loud sound that accompanied the tsunami. Hatori (1984), Imamura and Matsumoto (1998), Tsuji et al. (2002), and Imamura et al. (2002) estimated the tsunami heights by combining the damage described in the documents and/or oral histories passed down from generation to generation with land heights measured by recent field surveys. These estimates of tsunami heights have been compiled (Table 1, Figs. 3 and 4) and are used in this study. Multiple estimates at the same location by different investigators are averaged. Those heights based on oral histories rather than written documents tend to be consistently higher and are considered to be less reliable (Fig. 5). The tidal range in the Japan Sea is small, up to $0.5 \mathrm{~m}$, hence no correction for tide was made.

Along the Hokkaido coast, the 1741 tsunami caused the worst natural disaster in the Hokkaido's history, as described in many documents. One document, "Fukuyama Hifu", the official record of local government, reported that the tsunami arrived in the early morning of August 29 and inundated approximately a $120-\mathrm{km}$ length of the coastal areas, causing 1,467 casualties and damaging 791 houses and 1,521 ships. These numbers do not include native residents (Ainu) who occupied the area north of Kumaishi but did not leave any written records (Fig. 4). There is no written record of the tsunami damage on Okushiri Island. Hatori (1984), and Tsuji et al. (2002) estimated that the total casualties including Ainu would be more than 2,000.

The maximum estimated height based on the oral histories is $34 \mathrm{~m}$ at Gankakezawa, while the maximum height 
based on written records is about $13 \mathrm{~m}$ at Era (Table 1, Fig. 5). Conservative estimates of the tsunami height range from 3 to $13 \mathrm{~m}$ on the Hokkaido coast. The height distribution appears to show two peaks: one in the north around Kumaishi and the other at the southwestern tip of the peninsula around Era. Between these peaks, the estimated heights around Esashi are smaller. Some documents report that the sea water first receded at Kumaishi and Esashi (Tsuji et al., 2002), although the reliability is somewhat questionable.

The tsunami heights on the Honshu coasts were estimated by Hatori (1984) and Imamura et al. (2002). On the Tsugaru coast, the northern tip of Honshu, more than ten casualties and damage to several tens of houses were recorded at Kodomari and Kanegasawa. The tsunami heights at these and other villages were estimated to be between 4 and $6 \mathrm{~m}$ (Table 1, Fig. 5). On Sado Island, more than $350 \mathrm{~km}$ from Oshima-Oshima, the tsunami heights were estimated to be between 2 and $5 \mathrm{~m}$ based on descriptions of the damage, while the oral histories suggest a height of $8 \mathrm{~m}$. Damage from the tsunami was also documented further west at Noto, Obama, and Gohtsu, where the heights were estimated to be 4,1 , and $2 \mathrm{~m}$, respectively.

Damage from the tsunami was recorded as far as on the east coast of the Korean Peninsula. "Annals of Choson Dynasty" recorded tsunami damage along the east coast of Korean Peninsula on the same day (http://sillok.history.go.kr/ main/main.jsp). Tsuji et al. (1985) estimated that the tsunami heights were 3-4 m along the $320-\mathrm{km}$ long coast. Although the exact locations of the tsunami damage are not clear, this piece of information would provide an important constraint. In accordance with Tsuji et al. (1985), the Korean tsunami was assumed to be highest at Pyonhae, where it reached $4 \mathrm{~m}$; elsewhere along the $320 \mathrm{~km}$-long coast, it was assumed to reach a height of $3 \mathrm{~m}$ (Figs. 3 and 5).

\section{Submarine Landslide Models}

Tsunamigenic landslides can be classified as slumps and debris avalanches. Slumps are characterized by large blocks moving slowly and coherently, whereas debris avalanches are distinguished by many smaller masses of debris distributed over a larger area, suggesting fast-moving landslides. The slump source may be modeled by rigid body motion, particularly if the bathymetry change is known. The debris avalanches are more difficult to model; they can be modeled as slides of many rigid bodies or fluid flow. In any case, dynamic parameters, such as slide velocity, are needed.

The generation of a tsunami from landslides has been modeled in several ways, such as dynamic flow, kinematic rigid-body motion, and static initial profile. In the dynamic fluid flow approach, the landslide is treated as fluid, and its evolution is calculated simultaneously with the propagation of the tsunami (Jiang and LeBlond, 1994; Imamura and Imteaz, 1995; Heinrich et al., 1998). Kawamata et al. (2005) recently modeled the 1741 Oshima-Oshima tsunami using a two-layer model and volume change estimated by Satake and Kato (2001). In the rigid-body approach, temporal changes in the water height due to the progress of a submarine landslide are prescribed and used for the initial condition of tsunami propagation. Harbitz (1992) used a

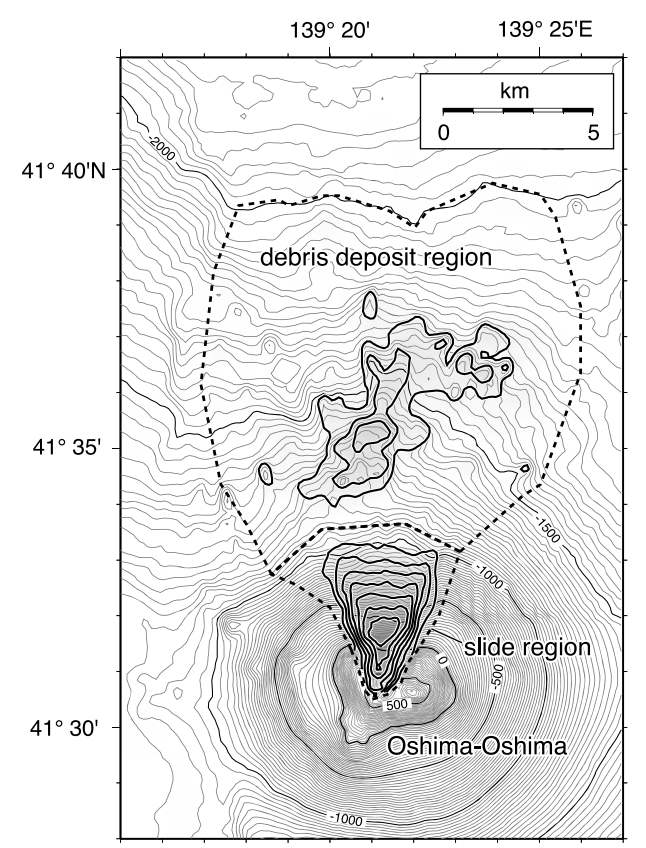

Fig. 6. Bathymetry after the landslide (contour interval: $25 \mathrm{~m}$ ) and inferred contours (interval: $50 \mathrm{~m}$ ) of the thickness of the material removed from the collapse scar (lower shaded region) and added to the landslide deposit region (upper). The thickness contours and the described volume are used for the tsunami computations. Based on the estimate of Satake and Kato (2001).

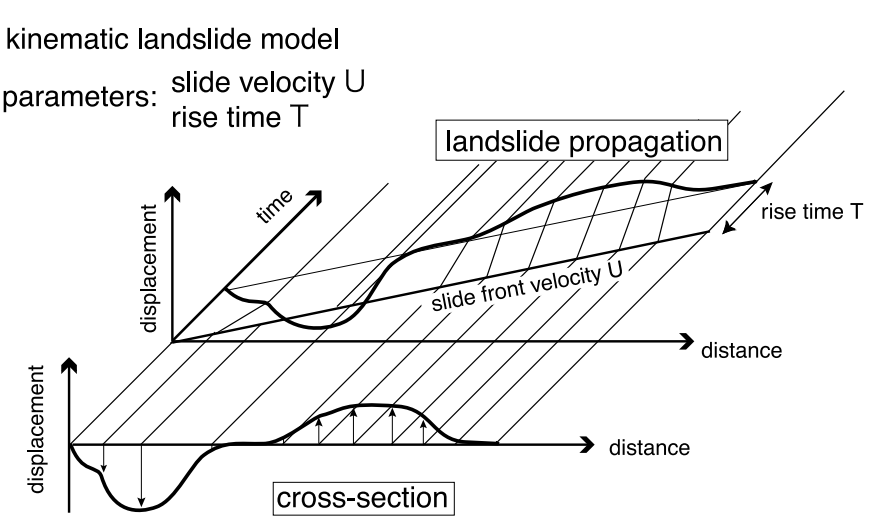

Fig. 7. Schematic view of the kinematic landslide model used in this study.

box-shaped slide, and Ward (2001) used a chain of rigid boxes. Tinti et al. (1997) introduced a block model of landslide to simulate the landslide motion, then used the results for tsunami computations. In the static approach, an initial water profile due to landslide is assumed. Watts et al. (2005), based on the results of physical and numerical experiments, introduced a parametric initial water profile for a submarine landslide and applied such a method to several landslide-generated tsunamis.

In this paper, a simple kinematic landslide model is introduced (Fig. 7). The volume change as shown in Fig. 6 is used as the initial water height distribution. The initial water height at each point, negative in the slide region and positive in the debris deposit region, is performed during rise time $T$. This assumption models a rotational slump rather than debris avalanches. To model the slide motion, we assume that the slide front propagates outward from the 
volcano peak with a horizontal velocity of $U$. Hence, the landslide motion is characterized by these two parameters, $U$ and $T$ (Fig. 7).

The kinematic slide model is similar to the kinematic source model of earthquakes known as the Haskell model (e.g., Aki and Richards, 1980), in which rise time and rupture duration (fault length divided by rupture velocity) are prescribed to compute seismic waveforms. The only difference between these two models is that the slip on the fault is uniform in the Haskell model, whereas the displacement varies in the kinematic landslide model. In the kinematic slide model, the slide (missing volume) first appears, then the deposit (additional volume) results. During the slide motion, the mass is not conserved. The kinematic landslide model was applied to the Nuuanu and Wailau giant submarine landslides around Hawaii, based on recently mapped detailed bathymetric data (Satake et al., 2002), but the landslide parameters were not calibrated with the observed tsunamis.

The area and volume of sector collapse associated with the 1741 Oshima-Oshima eruption is estimated to be $17 \pm 4$ $\mathrm{km}^{2}$ and $2.4 \pm 0.3 \mathrm{~km}^{3}$, respectively, by Satake and Kato (2001). They also estimated that the debris deposits extended into an area of $69 \pm 4 \mathrm{~km}^{2}$, with a total volume of $2.5 \pm 0.3 \mathrm{~km}^{3}$ (Fig. 6). The missing (slide) volume is located just north of the island, with a maximum thickness of $400 \pm 6 \mathrm{~m}$, while the excess (deposit) volume extends as far as $16 \mathrm{~km}$ from the island, with an average thickness of $36 \pm 2 \mathrm{~m}$. These values are used for the initial conditions of tsunami generation and propagation. They do not include thinner deposits of debris or debris avalanche extending over a wider area, as observed around Ritter Island (Silver et al., 2005), but such thinner deposits may not have contributed to the tsunami generation.

The computed tsunami heights from various landslide parameters in the kinematic slide model are compared with the observed tsunami heights. The horizontal slide velocity is varied from $U=10 \mathrm{~m} / \mathrm{s}$ to $100 \mathrm{~m} / \mathrm{s}$. At the time of the $1980 \mathrm{Mt}$. St. Helens eruption, the velocity of the first subaerial slide is estimated to be $50-70 \mathrm{~m} / \mathrm{s}$ from the analysis of a series of photographs (Voight, 1981). For the 1888 Ritter Island tsunami, Ward and Day (2003) used an estimated landslide deposit distribution and showed that the broad features of the observed tsunami could be reproduced using the tsunami model of Ward (2001) with landslide velocities of $40 \mathrm{~m} / \mathrm{s}$ or more. For the Storegga slides, Harbitz (1992) assigned $20 \mathrm{~m} / \mathrm{s}$ and $50 \mathrm{~m} / \mathrm{s}$ for the lower and upper limits of the submarine slide velocity. For the giant Hawaiian landslides, Satake et al. (2002) modeled three different velocities - 20,50, and $100 \mathrm{~m} / \mathrm{s}$ - and found that the tsunami heights from the latter two velocities were equally larger than those from $20 \mathrm{~m} / \mathrm{s}$ on both Hawaiian Islands and the west coast of North America.

Duration, or rise time, of bottom deformation at each point is more difficult to estimate. For earthquake tsunamis, Kajiura (1970) concluded that the deformation can be considered to be instantaneous if it is less than several minutes. While a landslide source may be smaller than an earthquake source, three different rise times, $T=1,2$, and $5 \mathrm{~min}$, are tested in this study. Because the displacement varies within the source area, the constant rise time implies that the local vertical velocity of bottom deformation also varies.

\section{Tsunami Propagation Modeling}

Tsunami propagation is calculated using nonlinear shallow-water equations. The equation of motion is

$$
\frac{\partial \boldsymbol{V}}{\partial t}+(\boldsymbol{V} \cdot \nabla) \boldsymbol{V}=-g \nabla h-C_{f} \frac{\boldsymbol{V}|\boldsymbol{V}|}{d+h}
$$

where $\boldsymbol{V}$ is the horizontal velocity vector, $h$ is the water (tsunami) height, $d$ is the water depth, and $g$ is the gravitational acceleration. The second term on the right of the equation represents the bottom friction where $C_{f}$ is the non-dimensional friction coefficient. In this study, depthdependent friction is assumed so that the coefficient is given with the Manning's roughness coefficient $n$ (assumed to be $0.03 \mathrm{~m}^{-1 / 3} \mathrm{~s}$ ) as

$$
C_{f}=\frac{g n^{2}}{(d+h)^{1 / 3}}
$$

The equation of continuity is written as

$$
\frac{\partial(d+h)}{\partial t}=-\nabla \cdot\{(d+h) \boldsymbol{V}\}
$$

The finite-difference method on a staggered grid system is adopted to numerically solve the above equations. The computations are made on two different grids. One is around the source area $\left(138.5-140.5^{\circ} \mathrm{E}\right.$ and $\left.40.5-42.5^{\circ} \mathrm{N}\right)$ with a grid spacing of $6^{\prime \prime}$ (arc second) or $185 \mathrm{~m}$ along the meridian (Fig. 4). The bathymetry data are compiled from JODC (Japan Oceanographic Data Center) data and recent bathymetric surveys (see Satake and Kato, 2001). The number of grid cells is $1200 \times 1200$, and the computational time step is $0.5 \mathrm{~s}$ to satisfy the stability condition of the finitedifference method. The generation and propagation of the tsunami for $45 \mathrm{~min}$ in real time are computed so that the full waveforms at all of the coastal points are obtained. The second grid is for the entire Japan Sea $\left(127-143^{\circ} \mathrm{E}\right.$ and $33-$ $52^{\circ} \mathrm{N}$ ) with a grid spacing of $1^{\prime}$ (arc minute) or $1,853 \mathrm{~m}$ along the meridian (Fig. 3). The bathymetric data are from the JODC database. The number of cells is $960 \times 1140$, and the computational time step is $5 \mathrm{~s}$ to satisfy the stability condition. The generation and propagation of the tsunami for 4 $\mathrm{h}$ in real time are computed.

Tsunami heights are computed at coastal points where they can be compared with the observed heights. In general, computed tsunami heights are smaller on coarser grids because of two factors: the computed water height is an average value for each grid cell, and the water depth on the coastal cell is shallower (e.g., Satake, 1995; Satake and Tanioka, 1995). The computed heights on different girds, the $6^{\prime \prime}$ and $1^{\prime}$ grids, are first compared on 34 coastal points in Hokkaido and Tsugaru. The average amplitude ratio (for peak-to-trough amplitude) is 0.54 , indicating that the computed tsunami heights on the $6^{\prime \prime}$ grid are about twofold larger than those on the $1^{\prime}$ grid. Therefore, a half of a peak-to-trough amplitude on the $6^{\prime \prime}$ grid and the peak-totrough amplitude on the $1^{\prime}$ grid are adopted as the computed tsunami heights. As shown in Fig. 5, these agree very well. 

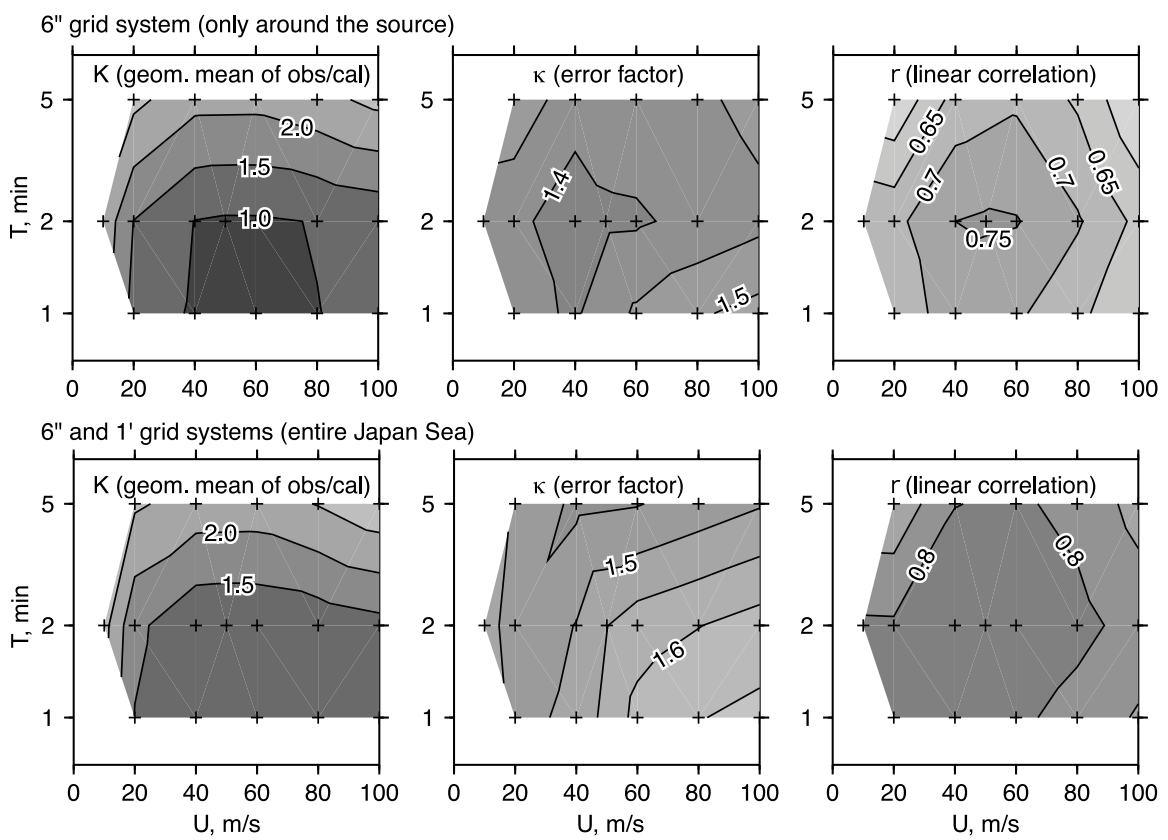

Fig. 8. Comparison of the statistical parameters for different sets of horizontal slide velocity $U$ and rise time $T$. The top row shows those for around the source on the $6^{\prime \prime}$ grid, while the bottom row is for the entire Japan Sea from both $6^{\prime \prime}$ and $1^{\prime}$ grids. The left column is the geometric mean of observed and computed amplitudes $K$. The center column is for the error factor $\kappa$. The right column is for linear correlation factor $r$. The darker color indicates the better fit between the observed and computed heights.

In order to carry out a comparison between the observed run-up heights and computed heights on coastal cells, three statistical parameters are introduced. The first is the geometric mean $K$ of the amplitude ratio $O_{i} / C_{i}$, where $O_{i}$ and $C_{i}$ are the observed and computed heights, respectively, at station $i$. The second is an index of scatter, defined by Aida (1978) as

$$
\log \kappa=\left[\frac{1}{n} \sum_{j}\left(\log \frac{O_{i}}{C_{i}}\right)^{2}-(\log K)^{2}\right]^{1 / 2} .
$$

If the logarithmic amplitude ratios obey the normal distribution $N(\log K, \log \kappa)$, then parameter $\kappa$ can be considered as an error factor because its logarithm shows the standard deviation. The third parameter is the linear correlation coefficient

$$
r=\frac{\sum_{i}\left(O_{i}-\bar{O}\right)\left(C_{i}-\bar{C}\right)}{\sqrt{\sum_{i}\left(O_{i}-\bar{O}\right)^{2}} \sqrt{\sum_{i}\left(C_{i}-\bar{C}\right)^{2}}}
$$

where $\bar{O}$ and $\bar{C}$ are the means of $O_{i}$ 's and $C_{i}$ 's, respectively.

The first parameter, $K$, indicates the relative size of the observed and computed tsunami models, whereas the latter two indicate the goodness of the model. The smaller $\kappa$ and the larger $r$ are the measures of the better model.

\section{Tsunami Computation Results}

The tsunami generation is computed using the kinematic landslide model, and the propagation is computed for both the $6^{\prime \prime}$ and $1^{\prime}$ grids. The computations are repeated with different sets of horizontal slide velocity $U$ and rise time $T$ (Table 2). The computed tsunami heights are then compared with the observed ones, and the statistical parameters $K, \kappa$ and $r$ are calculated. These parameters are calculated for two different regions: the coasts near the source on the 6 " grid and the entire Japan Sea for which the computed heights are on the $6^{\prime \prime}$ grid around the source and those are on the $1^{\prime}$ grid for the western Japan and Korean coasts.

The amplitude ratio $K$, the error factor $\kappa$ and the linear correlation factor $r$ vary with the assumed parameters (Fig. 8). The $K$ values are close to 1 for $U=40-80 \mathrm{~m} / \mathrm{s}$ and $T \leq 2 \mathrm{~min}$. The error factor shows a peak (trough in $\kappa$ value) at $U=40-60 \mathrm{~m} / \mathrm{s}$ and $T=2 \mathrm{~min}$ for the $6^{\prime \prime}$ grid. With the larger peak value (smaller $\kappa$ value), the peak is shifted to $T=5 \mathrm{~min}$ for the entire Japan Sea. The linear correlation factor $r$ also shows a peak at $U=40-60 \mathrm{~m} / \mathrm{s}$ and $T=2 \mathrm{~min}$ for the $6^{\prime \prime}$ grid. For the entire Japan Sea, the peak is located at the same place, although the shape is rather broad. From these comparisons, it can be concluded that the kinematic landslide model with $U=40 \mathrm{~m} / \mathrm{s}$ and $T=2$ min best explains the observed tsunami heights. For this combination, $K=0.99, \kappa=1.37$, and $r=0.75$ for the near-source region, and $K=1.11, \kappa=1.50$, and $r=0.84$ for the entire Japan Sea.

For comparison, Kawamata et al. (2005) also estimated $K$ and $\kappa$ values for their earthquake fault and two-layer slide models. Their fault model yielded $K=0.89$ and $\kappa=1.38$ for the near-source region, and $K=1.00$ and $\kappa=1.68$ for the entire Japan Sea. Their two-layer slide model yielded $K=0.99$ and $\kappa=1.76$ for the near-source region, and $K=1.01$ and $\kappa=1.58$ for the entire Japan Sea. The smaller $\kappa$ values in the present model indicate that our model shows a better fit with the distribution of the observed tsunami heights.

The effects of the kinematic landslide parameters on the coastal tsunami heights are also examined (Fig. 9). For comparison, the observed tsunami heights are also shown. The horizontal slide velocity is first fixed at $U=40 \mathrm{~m} / \mathrm{s}$ and the rise time is varied as $T=1,2$, and $5 \mathrm{~min}$ (top figure). 
Table 2. Comparison of parameters for various models

\begin{tabular}{cccccccc}
\hline$U(\mathrm{~m} / \mathrm{s})$ & $T(\mathrm{~min})$ & \multicolumn{3}{c}{$6^{\prime \prime}$ grid $(n=36)$} & \multicolumn{3}{c}{$1^{\prime}$ and 6" grids $(n=49)$} \\
& & $K$ & $\kappa$ & $r$ & $K$ & $\kappa$ & $r$ \\
\hline 20 & 1 & 1.34 & 1.42 & 0.68 & 1.48 & 1.48 & 0.80 \\
40 & 1 & 0.93 & 1.39 & 0.72 & 1.04 & 1.52 & 0.82 \\
60 & 1 & 0.90 & 1.46 & 0.71 & 1.04 & 1.62 & 0.81 \\
80 & 1 & 0.99 & 1.49 & 0.66 & 1.15 & 1.65 & 0.78 \\
100 & 1 & 1.11 & 1.52 & 0.60 & 1.28 & 1.66 & 0.74 \\
10 & 2 & 2.35 & 1.42 & 0.70 & 2.66 & 1.53 & 0.81 \\
20 & 2 & 1.49 & 1.41 & 0.69 & 1.62 & 1.46 & 0.81 \\
$\mathbf{4 0}$ & $\mathbf{2}$ & $\mathbf{0 . 9 9}$ & $\mathbf{1 . 3 7}$ & $\mathbf{0 . 7 5}$ & $\mathbf{1 . 1 1}$ & $\mathbf{1 . 5 0}$ & $\mathbf{0 . 8 4}$ \\
50 & 2 & 0.94 & 1.39 & 0.76 & 1.09 & 1.55 & 0.85 \\
60 & 2 & 0.94 & 1.39 & 0.75 & 1.11 & 1.58 & 0.84 \\
80 & 2 & 1.02 & 1.41 & 0.71 & 1.20 & 1.60 & 0.82 \\
100 & 2 & 1.14 & 1.44 & 0.64 & 1.34 & 1.62 & 0.78 \\
20 & 5 & 2.64 & 1.49 & 0.56 & 2.57 & 1.49 & 0.71 \\
40 & 5 & 2.16 & 1.42 & 0.67 & 2.29 & 1.44 & 0.80 \\
60 & 5 & 2.15 & 1.43 & 0.69 & 2.27 & 1.45 & 0.81 \\
80 & 5 & 2.34 & 1.44 & 0.64 & 2.52 & 1.47 & 0.78 \\
100 & 5 & 2.63 & 1.47 & 0.55 & 2.86 & 1.50 & 0.73 \\
\hline
\end{tabular}
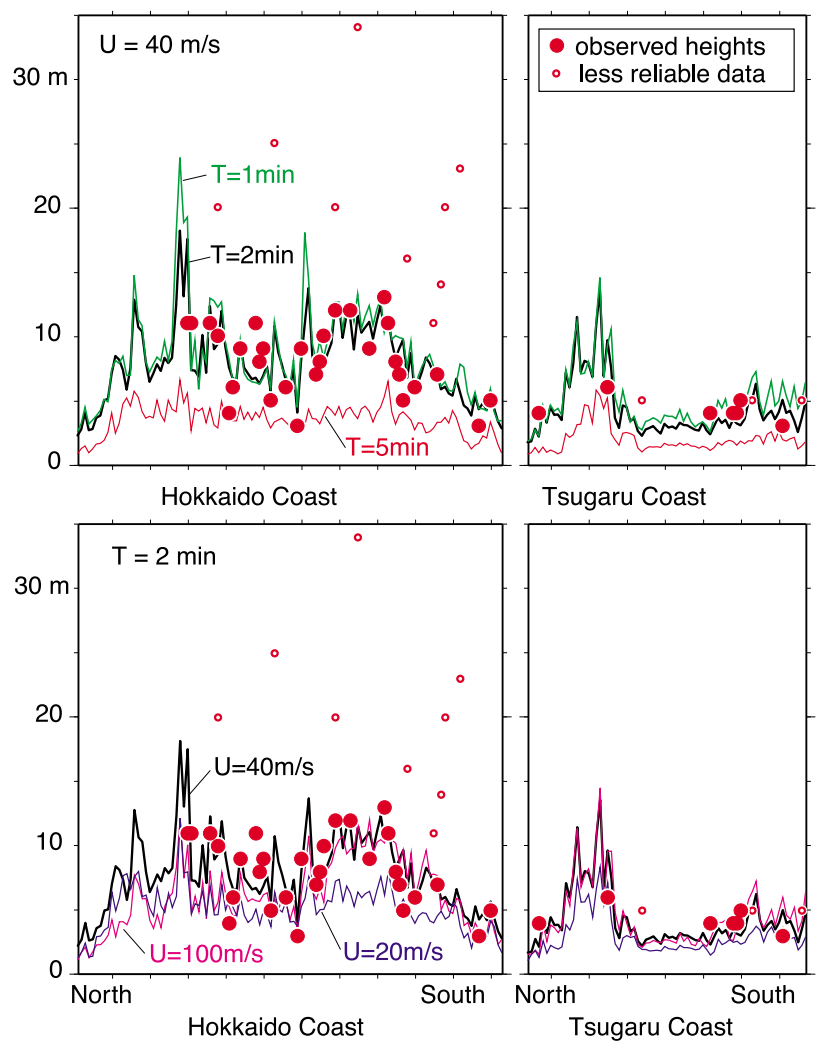

Fig. 9. Tsunami heights computed for different landslide parameters in the kinematic landslide model. The observed tsunami heights are also shown for comparison. Top: The horizontal slide velocity is fixed at $U=40 \mathrm{~m} / \mathrm{s}$ and the rise time $T$ is varied as 1,2 , and $5 \mathrm{~min}$. Bottom: The rise time $T$ is fixed at $2 \mathrm{~min}$ and the horizontal slide velocity varied as $U=20,40$, and $100 \mathrm{~m} / \mathrm{s}$. Those for $U=60$ and $80 \mathrm{~m} / \mathrm{s}$ are similar to the $40 \mathrm{~m} / \mathrm{s}$ case and are, therefore, not shown.

The computed tsunami heights for $T=5 \mathrm{~min}$ are systematically lower than the other cases or the observations. The computed heights for $T=1 \mathrm{~min}$ and $2 \mathrm{~min}$ are similar, although the former has larger narrow peaks. In the next step, the rise time is fixed at $T=2 \mathrm{~min}$ and the velocity is varied as $U=20,40$, and $100 \mathrm{~m} / \mathrm{s}$ (lower figure). The computed heights for $U=40 \mathrm{~m} / \mathrm{s}$ are similar to the observed heights on the Hokkaido coast. The computed heights for $U=20 \mathrm{~m} / \mathrm{s}$ are lower on the Hokkaido coast, and those from $U=100$ $\mathrm{m} / \mathrm{s}$ are also lower on the northern Hokkaido coast. The tsunami heights for $U=60$ and $80 \mathrm{~m} / \mathrm{s}$ are similar to those for $U=40 \mathrm{~m} / \mathrm{s}$ and are, therefore, not shown. The computed tsunami heights for different slide velocities are similar on the Tsugaru coast. These comparisons indicate that the tsunami heights on the Hokkaido coasts are more sensitive to the slide parameters than those on the Tsuguru coast.

Tsunami waveforms calculated from different parameters show different features. Figure 10 shows the computed tsunami waveforms at four selected locations, Kumaishi, Esashi, Era, and Ajigasawa. For the same slide velocity ( $U=40 \mathrm{~m} / \mathrm{s}$ ), the waveforms and amplitudes are similar for $T=1$ and $2 \mathrm{~min}$, while that for $T=5 \mathrm{~min}$ is considerably different, with smaller amplitudes. This feature is common to all of the locations regardless of the azimuth. For the same rise time ( $T=2 \mathrm{~min}$ ), the faster slide velocity produces the earlier arrival time. At Kumaishi (northeastern azimuth), the amplitude is largest for $U=40 \mathrm{~m} / \mathrm{s}$. At other locations, the waveforms and amplitudes for $U=40-100 \mathrm{~m} / \mathrm{s}$ are very similar. All of the waveforms start with negative motions, which is consistent with the report that the water initially receded at Kumaishi and Esashi (Tsuji et al., 2002).

\section{Discussion}

The 1741 tsunami can be explained by a submarine landslide associated with the sector collapse of the OshimaOshima volcano. While the length of the submarine landslide is much larger than the volcano $(\sim 4 \mathrm{~km})$, it still reaches only $16 \mathrm{~km}$, which is much smaller than the typical size of tsunamigenic earthquakes $(\sim 100 \mathrm{~km})$. An interesting question is why this submarine landslide was able to cause such a large tsunami equivalent to an earthquake of $M=8.4$ (Abe, 1999). Two factors appear to have contributed to the large tsunami: the large vertical drop and the coupling of the landslide and tsunami.

Ruff (2003) examined the energy balance for tsunamis generated from landslides and earthquakes. Using a simple block model, he showed that the tsunami becomes the largest when the ratio of initial water depth above the block 

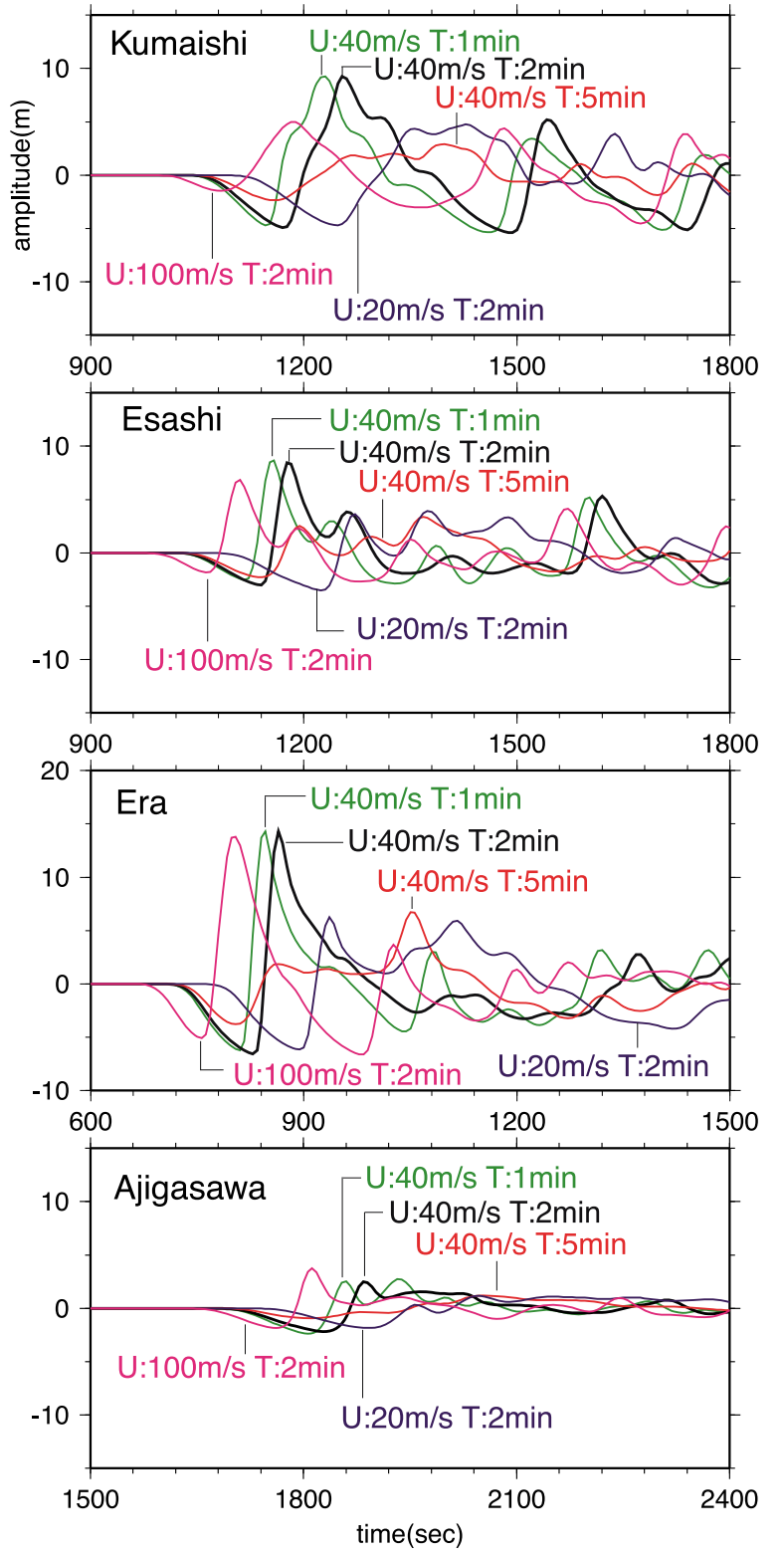

Fig. 10. Computed tsunami waveforms from different landslide models at Kumaishi, Esashi, Era, and Ajigasawa (see Fig. 4 for the locations). The tsunami heights from the kinematic slide model with parameters $(U, T)=(40 \mathrm{~m} / \mathrm{s}, 1 \mathrm{~min}),(40 \mathrm{~m} / \mathrm{s}, 2 \mathrm{~min}),(40 \mathrm{~m} / \mathrm{s}, 5 \mathrm{~min}),(20 \mathrm{~m} / \mathrm{s}, 2$ $\mathrm{min}),(100 \mathrm{~m} / \mathrm{s}, 2 \mathrm{~min})$ are shown.

to downslope vertical drop of the block is less than 1 . In the case of Oshima-Oshima, the slide top is above sea level, hence the water depth is smaller than the vertical drop and the ratio is indeed less than 1 . If the slide were to have been limited to a small part of the ocean slope around the island, the tsunami energy would have been smaller.

When the slide velocity is similar to the local tsunami velocity, the coupling effects amplify the tsunami in the direction of propagation (Ward, 2001). In the case of OshimaOshima, the water depth in the tsunami source area is 0 $2000 \mathrm{~m}$, where the tsunami velocity ranges $0-140 \mathrm{~m} / \mathrm{s}$. Hence the propagating submarine landslide may cause coupling with tsunami. The slide was thickest (nearly $400 \mathrm{~m}$ ) at a water depth of around $200 \mathrm{~m}$ (Fig. 6), where the tsunami velocity is about $40 \mathrm{~m} / \mathrm{s}$. Hence, the landslide propagat- ing at $U=40 \mathrm{~m} / \mathrm{s}$ causes possible coupling with propagating tsunamis and the amplitudes become large.

\section{Conclusions}

The 1741 Oshima-Oshima tsunami can be explained to be the result of a partly submarine lateral collapse of the north flank of the Oshima-Oshima volcano. No tectonic earthquake source is required, which is consistent with the lack of evidence for such an earthquake in the historical records. The tsunami heights are computed on two different grids - a $6^{\prime \prime}$ grid near the source and a $1^{\prime}$ grid for the entire Japan Sea. A parameter search for the simple kinematic landslide model indicates that the observed values are best explained for the combination of $U=40 \mathrm{~m} / \mathrm{s}$ and $T=2 \mathrm{~min}$. The slide velocity is similar to the tsunami phase velocity in the source area, indicating that landslide and tsunamis were coupled to generate the large tsunami heights. The large vertical drop of the slide, from the surface of the water to the deep seafloor, was also responsible for creating the large tsunamis.

The simple kinematic landslide model predicts a larger tsunami in the northern direction than what was observed in the southern and western directions. Future studies on this tsunami may include more realistic dynamic modeling for debris avalanches and a search for tsunami deposits on the coasts of Hokkaido and Okushiri Island as well as historical records in Russian and Chinese archives across the Japan Sea.

Acknowledgments. The reviews provided by Simon Day and Tadahide Ui were very helpful in improving the manuscript. Discussions with Stefano Tinti on the kinematic slide model was useful in improving the model. Shigeru Yamaki helped compile the field measurements data, and Yushiro Fujii carefully checked the manuscript and provided useful comments. For processing and plotting of bathymetry data, GMT software package (Wessel and Smith, 1998) was used.

\section{References}

Abe, K., Quantification of historical tsunamis by the $M_{t}$ scale, Zisin ( $J$. Seism. Soc. Jpn), 52, 369-377, 1999 (in Japanese with English abstract). Aki, K. and P. G. Richards, Quantitative Seismology, Vol. II, W. H, Freeman and Company. 932 pp, 1980.

Aida, I., Reliability of a tsunami source model derived from fault parameters, J. Phys. Earth, 26, 57-73, 1978.

Aida, I., An estimation of tsunamis generated by volcanic eruptions-the 1741 eruption of Oshima-Ohshima, Hokkaido, Bull. Earthq. Res. Inst. Univ. Tokyo, 59, 519-531, 1984 (in Japanese with English abstract).

Fukao, Y. and M. Furumoto, Mechanism of large earthquakes along the eastern margin of the Japan Sea, Tectonophysics, 26, 247-266, 1975.

Harbitz, C. B., Model simulations of tsunamis generated by the Storegga slides, Mar. Geology, 105, 1-21, 1992.

Hatori, T., Reexamination of wave behavior of the Hokkaido-Oshima (the Japane Sea) tsunami in 1741 - their comparison with the 1983 Nihonkai-chubu tsunami, Bull. Earthq. Res. Inst. Univ. Tokyo, 59, 115125, 1984 (in Japanese with English abstract).

Hatori, T., Hokkaido Nansei-oki earthquake tsunami and seismic gap, Gekkan Chikyu (Earth Monthly), suppl. 7, 211-218, 1994 (in Japanese).

Heinrich, P., A. Mangeney, S. Guibourg, R. Roche, G. Boudon, and J.L. Cheminee, Simulation of water waves generated by a potential debris avalanche in Montserrat, Lesser Antilles, Geophys. Res. Lett., 25, 36973700, 1998.

Imamura, F. and M. M. A. Imteaz, Long waves in two-layers: governing equations and numerical model, Sci. Tsunami Hazards, 13, 3-24, 1995. Imamura, F. and T. Matsumoto, Field survey of the 1741 OshimaOshima volcanic tsunami, Tsunami Engineering Technical Report, Tohoku Univ., 15, 85-105, 1998 (in Japanese). 
Imamura, F., S. Okubo, K. Ban, K. Takaoka, A. Sannomiya, S. Yamaki, and E. Kobayashi, Field investigation on the 1741 Kampo Oshima tsunami in Tsugaru peninsula, the northern part of Japan-Detailed survey with additional document "Tsugaru-han Okuni Nikki", Rekishi Jishin (Historical Earthquakes), 18, 166-175, 2002 (in Japanese).

Jiang, L. and P. LeBlond, 3-Dimensional modeling of tsunami generation due to a submarine mudslide, J. Phys. Ocean, 24, 559-572, 1994.

Johnson, R. W., Large-scale volcanic cone collapse: the 1888 slope failure of Ritter Volcano, and other examples from Papua New Guinea, Bull. Volcanol, 49, 669-679, 1987.

Kajiura, K., Tsunami source, energy and the directivity of wave radiation, Bull. Earthq. Res. Inst. Univ. Tokyo, 48, 835-869, 1970.

Kato, Y., Topography and geology of the sector collapse deposit of the Oshima-Oshima island, JAMSTEC J. Deep Sea Res., 13, 659-667, 1997 (in Japanese with English abstract).

Katsui, Y. and M. Yamamoto, The 1741-1742 activity of Oshima-oshima volcano, north Japan, J. Fac. Sci. Hokkaido Univ. Ser. IV, 19, 527-536, 1981.

Katsui, Y., I. Yokoyama, S. Ehara, H. Yamashita, K. Hiida, and M. Yamamoto, Oshima-Oshima. Report of the Volcanoes in Hokkaido, part.6. Committee for Prevention of the Natural Disasters of Hokkaido, Sapporo, 82 pp., 1977 (in Japanese).

Kawamata, K, K, Takaoka, K. Ban, F. Imamura, S. Yamaki, and E. Kobayashi, Model of tsunami generation by collapse of volcanic eruption: the 1741 Oshima-Oshima tsunami, in Tsunamis: Case Studies and Recent Developments, edited by K. Satake, Springer, 79-96, 2005.

Kokelaar, P. and C. Romagnoli, Sector collapse, sedimentation and clast population evolution at an active island-arc volcano: Stromboli, Italy, Bull. Volcanol., 57, 240-262, 1995.

Nakamura, K., Possible nascent trench along the eastern Japan Sea as the boundary between Eurasian and North American plates, Bull. Earthq. Res. Inst. Univ. Tokyo, 58, 711-722, 1983 (in Japanese with English abstract).

Ohtake, M., A seismic gap in the eastern margin of the Japan Sea as inferred from the time-space distribution of past seismicity, The Island Arc, 4, 156-165, 1995.

Ruff, L. J., Some aspects of energy balance and tsunami generation by earthquakes and tsunamis, Pure Appl. Geophys., 160, 2155-2176, 2003.

Satake, K., Re-examination of the 1940 Shakotan-oki earthquake and the fault parameters of the earthquakes along the eastern margin of the Japan Sea, Phys. Earth Planet. Inter., 43, 137-147, 1986.

Satake, K., Linear and non-linear computations of the 1992 Nicaragua earthquake tsunami, Pure and Applied Geophysics, 144, 455-470, 1995.

Satake, K. and Y. Kato, The 1741 Oshima-Oshima Eruption: Extent and Volume of Submarine Debris Avalanche, Geophys. Res. Lett., 28, 427430, 2001.

Satake, K. and Y. Tanioka, Tsunami generation of the 1993 Hokkaido Nansei-oki earthquake, Pure Appl. Geophys., 144, 803-821, 1995.

Satake, K., J. R. Smith, and K. Shinozaki, Three-dimensional reconstruction and tsunami model of the Nuuanu and Wailau giant landslides,
Hawaii, in Hawaiian Volcanoes: Deep Underwater Perspectives, edited by Takahashi et al., AGU Geophysical Monograph, 128, 333-346, 2002.

Seno, T., T. Sakurai, and S. Stein, Can the Okhotsk plate be discriminated from the North American plate?, J. Geophys. Res., 101, 11305-11351, 1996.

Silver, E., S. Day, S. Ward, G. Hoffmann, P. Llanes, A. Lyons, N. Driscoll, R. Perembo, S. John, S. Saunders, F. Taranu, L. Anton, I. Abiari, B. Appelgate, J. Engels, J. Smith, and J. Taglioides, Island arc debris avalanches and tsunami generation, Eos Trans. AGU, 86, 485, 489 , 2005.

Tanioka, Y., K. Satake, and L. Ruff, Total analysis of the 1993 Hokkaido Nansei-oki earthquake using seismic wave, tsunami, and geodetic data, Geophys. Res. Lett., 22, 9-12, 1995.

Tinti, S., E. Bortolucci, and C. Vannini, A block-based theoretical model suited to gravitational sliding, Nat. Hazards, 16, 1-28, 1997.

Tinti, S., A. Maramai, A. Armigliato, L. Graziani, A. Manucci, G. Pagnoni, and F. Zaniboni, Observations of physical effects from tsunamis of December 30, 2002 at Stromboli volcano, southern Italy, Bull. Volcanol., 68, 450-561, 2005.

Tsuji, Y., W. S. Baek, K. S. Chu, and H. S. An, Report of the 1983 Nihonkai-Chubu earthquake tsunami along the east coast of the Republic of Korea, Review of Research for Disaster Prevention, No.90, National Research Center for Disaster Prevention, Ibaraki, Japan, 96 pp., 1985 (in Japanese with English abstract).

Tsuji, Y., T. Nishihata, T. Sato, and K. Sato, Distribution of heights of the tsunami caused by the 1741 Kampo eruption of volcano OshimaOshima, Hokkaido, Gekkan Kaiyo special issue, 28, 15-44, 2002 (in Japanese).

Voight, B., Time scale for the first moments of the May 18 eruption, in The 1980 Eruption of Mount St. Helens, Washington, edited by P. W. Lipman and D. R. Mullineaux, USGS Professional Paper, 1250, pp. 6986, 1981.

Voight, B., H. Glicken, R. J. Janda, and P. M. Douglass, Catastrophic rockslide avalanche of May 18, in The 1980 Eruption of Mount St. Helens, Washington, edited by P. W. Lipman and D. R. Mullineaux, USGS Professional Paper, 1250, pp. 347-377, 1981.

Ward, S. N, Landslide tsunami, J. Geophys. Res., 106, 11201-11216, 2001 Ward, S. N. and S. Day, Ritter Island Volcano- Lateral collapse and the tsunami of 1888, Geophys. J. Int., 154, 891-902, 2003.

Watts, P., S. T. Grilli, D. R. Tappin, and G. J. Fryer, Tsunami Generation by Submarine Mass Failure. II: Predictive equations and case studies, $J$. Waterway, Port, Coastal Ocean Engin, 131, 298-310, 2005.

Wei, D. and T. Seno, Determination of the Amurian plate motion, in Mantle Dynamics and Plate Interactions in East Asia, edited by Flower et al., AGU Geodynamics Series, 27, pp. 337-346, 1998.

Wessel, P. and W. H. F. Smith, New, improved version of Generic Mapping Tools released, Eos Trans. AGU, 79, 579, 1998.

K. Satake (e-mail: kenji.satake@aist.go.jp) 